\title{
IMPLEMENTASI PERANGKAT LUNAK WIKIBUDAYA DALAM RANGKA MELESTARIKAN BUDAYA BANGSA DAN KEARIFAN LOKAL NUSANTARA
}

\author{
Feby Artwodini Muqtadiroh ${ }^{1)}$, Amna Shifia Nisafani ${ }^{2)}$, Fazlurrani Izzattisselim ${ }^{3)}$ \\ Jurusan Sistem Informasi, Fakultas Teknologi Informasi, Institut Teknologi Sepuluh Nopember \\ Kampus ITS Sukolilo, Surabaya, 60111 \\ Telp : (031) 5999944, Fax : (031) 5964965 \\ E-mail : feby@is.its.ac.id ${ }^{1)}$, amnashifia@its-sby.edu ${ }^{2)}$, fazlurrani.aegis46@ gmail.com $^{3)}$
}

\begin{abstract}
WikiBudaya is a repository website containing the cultural information in Indonesia. The aim of WikiBudaya is to preserve the nation's cultural and to preserve the local wisdom. The software development without any structured implementation will interfere the delivery of software goal development and eliminate the usefulness of software. Therefore WikiBudaya that have been developed do not go unpunished and is needed a process of implementation as a follow-up activities into the development of software to be used by all people.

The implementation process of WikiBudaya is a process of preparation, implementation, and the use of software. In this study conducted few steps which are planning, execution and closing that refers to the PMBOK (Project Management Body of Knowledge). And at every step in the implementation process of WikiBudaya consists of several activities related to the interaction beetwen software and the user by means of documentation, installation, dissemination, and user training.

The end result of implementation of WikiBudaya is the compliance of software implementation planning documents in the form of Work Breakdown Structure (WBS) to the achievement of $85 \%$ of the activities are fulfilled. The software documentation for users as well as the realization of the implementation of the activities that have been listed on the software implementation planning documents of WikiBudaya is useful to support the objectives of conservation of Indonesian culture by utilizing the information technology through the cultural repository website of WikiBudaya.
\end{abstract}

\section{Abstrak}

WikiBudaya adalah sebuah situs repositori yang berisi informasi mengenai kebudayaan di Indonesia. WikiBudaya dikembangkan dengan tujuan dapat menjadi solusi pelestarian kebudayaan bangsa dan kearifan lokal nusantara. Pengembangan perangkat lunak yang tidak disertai dengan implementasi yang terstruktur akan menghambat penyampaian tujuan pengembangan dan menghilangkan kemanfaatan perangkat lunak. Karena itu WikiBudaya yang telah selesai dikembangkan tidak dibiarkan begitu saja dan perlu adanya sebuah proses implementasi sebagai kegiatan yang menjadi tindak lanjut pengembangan perangkat lunak agar dapat digunakan oleh seluruh masyarakat.

Proses implementasi perangkat lunak WikiBudaya merupakan sebuah proses persiapan, penerapan dan penggunaan perangkat lunak oleh publik. Dalam penelitian ini dilakukan beberapa langkah pengerjaan yakni planning, execution dan closing yang mengacu pada PMBOK (Project Management Body of Knowledge). Dan di setiap langkap pada proses implementasi WikiBudaya terdiri dari beberapa kegiatan terkait dengan interaksi perangkat lunak dengan pengguna seperti dokumentasi, instalasi, sosialisasi dan pelatihan pengguna.

Hasil akhir dari kegiatan implementasi WikiBudaya berupa dokumen perencanaan implementasi perangkat lunak berupa Work Breakdown Structure (WBS) dengan pencapaian 85\% terpenuhi, dokumentasi perangkat lunak untuk pengguna serta realisasi aktivitas implementasi yang telah tertera pada dokumen perencanaan implementasi perangkat lunak WikiBudaya guna mendukung tujuan pelestarian kebudayaan Indonesia dengan memanfaatkan kemajuan teknologi informasi yang ada melalui situs repositori budaya Indonesia WikiBudaya.

Kata kunci: implementasi perangkat lunak, PMBOK, WBS, WikiBudaya, pelestarian budaya

\section{PENDAHULUAN}

Kebudayaan merupakan salah satu aset kebanggaan yang dimiliki oleh negara Indonesia. Kebudayaan serta tradisi tradisional
Indonesia tersebar luas dari Sabang hingga Merauke sehingga menyebabkan sebagian besar warga negara Indonesia kesulitan untuk memahami atau bahkan hanya untuk menghafalkan keberagaman budaya asli 
Muqtadiroh, dkk., Implementasi Perangkat Lunak WikiBudaya..

Indonesia. Menurunnya pemahaman warga negara Indonesia terhadap kebudayaan asli Indonesia ini, mengakibatkan menurunnya minat warga negara Indonesia dalam aktivitas pelestarian budaya Indonesia (Samantha, 2011). Menurunnya aktivitas pelestarian kebudayaan Indonesia oleh masyarakat ini banyak disebabkan oleh kurangnya perhatian pemerintah untuk memfasilitasi masyarakat untuk mengenal budaya Indonesia. Selain itu belum ada upaya untuk mengajak masyarakat Indonesia berperan serta aktif sehingga informasi terkait kebudayaan dan rasa ingin tahu masyarakat sangat minim (Sasongko, 2011). Karena hal - hal tersebut muncullah sebuah pemikiran untuk pelestarian kebudayaan Indonesia dengan memanfaatkan kemajuan teknologi informasi yang ada melalui WikiBudaya (Ahmad, Feby Artwodini, Amna Shifia, \& Ika, 2012).

Situs WikiBudaya dibangun untuk memenuhi kebutuhan publik terhadap pemahaman budaya Indonesia. Situs WikiBudaya ini tidak akan mencapai tujuan pengembangannya apabila tidak ada kegiatan yang menjadi tindak lanjut yang dilakukan. Penting untuk dilakukan proses implementasi perangkat lunak WikiBudaya sebagai aktivitas tindak lanjut sehingga kemanfaatan yang ditawarkan oleh perangkat lunak akhirnya dapat tersampaikan dengan baik. Urgensi dari aktivitas implementasi perangkat lunak WikiBudaya tergolong penting, karena meskipun perangkat lunak telah melewati proses evaluasi belum tentu penggunaan perangkat lunak akan berjalan lancar dan tidak mengalami gangguan non-teknis. Karena kesuksesan penggunaan sebuah perangkat lunak bukan hanya berdasarkan pada faktor teknis tetapi juga peran lingkungan serta manusia sebagai pihak pengguna akhir sangatkah vital (Jeffrey A. Hoffer, Joey F. George, 2012).

Hal tersebut relevan dengan riset Standish Group (StandishGroup, 2010) menyatakan bahwa hanya $10 \%$ dari perusahaan yang mampu untuk menerapkan perangkat lunak, 35\% proyek dibatalkan, dan $55 \%$ mengalami keterlambatan.

Sedangkan menurut Suryanto dkk (Suryanto, Gondodiyoto, NI, Aryanto, \& Triana, 2009) memberikan contoh proyek yang mengalami kemunduran selama satu tahun lebih. Proyek dimulai bulan Maret 2005, direncanakan selesai pada bulan Januari 2007. Namun sampai penelitian dilakukan, status proyek masih $90 \%$. Permasalahan yang muncul adalah dikarenakan kegiatan data mapping dan data migrasi. Proyek tersebut ditangani oleh dua pihak, sehingga mempunyai risiko untuk gagal lebih besar dibandingkan dengan proyek yang ditangani satu pihak. Dalam penelitannya dijelaskan bahwa penyebab kemunduran proyek adalah karena proyek kurang terencana dengan baik, dan permintaan kebutuhan dari pengguna tidak ada batasnya yang menyebabkan penambahan waktu dan biaya.

Dari gambaran di atas terlihat bahwa banyak kasus kegagalan implementasi proyek perangkat lunak yang berakibat pada tidak tersampaikannya tujuan pengembangan perangkat lunak dengan baik kepada seluruh pengguna.

Implementasi merupakan kegiatan pengembangan perangkat lunak sehingga dapat mencapai tujuan pengembangannya. Implementasi perangkat lunak merupakan sebuah proses persiapan, penerapan dan penggunaan perangkat lunak oleh publik. Proses implementasi berisikan beberapa kegiatan terkait dengan interaksi perangkat lunak dengan penggunanya seperti dokumentasi, instalasi serta sosialisasi. Proses implementasi sendiri dilakukan dengan tujuan untuk melanjutkan fungsi utama perangkat lunak serta tujuan pengembangannya kepada publik. Sebuah perangkat lunak yang telah selesai dikembangkan tentu belum dapat dirasakan manfaat serta tujuannya sebelum dilakukan proses implementasi (Project Management Institute, 2001).

Karena itulah, penelitian ini akan melakukan proses implementasi perangkat lunak WikiBudaya sebagai aktivitas tindak lanjut dari perangkat lunak ini sehingga kemanfaatan yang ditawarkan oleh perangkat lunak ini akhirnya dapat tersampaikan dengan baik yakni dalam rangka pelestarian budaya dan kearifan lokal nusantara.

WikiBudaya merupakan website ensiklopedia yang khusus mengelola informasi dan pengetahuan mengenai budaya di Indonesia dalam bentuk artikel dan teknologi repositori yang dapat diakses oleh seluruh lapisan masyarakat Indonesia (Feby Artwodini, Amna Shifia, \& Mochammad, 2014). Website WikiBudaya adalah bagian dari sitem grand design virtualNusantara sebagai pemanfaatan teknologi terintegrasi untuk pelestarian budaya dan kearifan lokal bangsa (Ahmad et al., 2012). Website WikiBudaya nantinya diharapkan dapat dikelola secara resmi oleh pemerintah melalui Dinas Kebudayaan dan Pariwisata (Disbudpar).

Keunggulan website WikiBudaya adalah pada sistem pengelolaan artikel yang ditampilkan telah melalui filtrasi atau penyaringan yang berlapis, sehingga dapat dipastikan jika artikelartikel yang ditampilkan adalah valid sesuai dengan keadaan sesungguhnya. Semua artikel budaya pada WikiBudaya telah melalui tahapan 
validasi artikel yang dilakukan oleh tim Reviewer. Reviewer adalah orang/pihak yang ditunjuk untuk melakukan validasi artikel budaya. Secara umum fungsi dari WikiBudaya hampir sama dengan situs ensiklopedia Wikipedia.

Tetapi website Wikipedia tidak memiliki sistem penyaringan dan verifikasi artikel yang berlapis. Pengguna dapat mengunggah dan mengubah artikel dengan bebas. Dengan demikian, perbedaannya dengan WikiBudaya memberikan informasi tentang budaya untuk melestarikan kebudayaan bangsa dan kearifan lokal yang artikelnya telah valid dan memiliki kekayaan intelektual yang melalui proses penilaian dari Disbudpar sebagai nilai keunggulannya. Hak akses pengguna juga diatur dalam sistem pada website WikiBudaya. Hak akses pengguna dibagi menjadi dua, yaitu Reviewer dan Kontributor. WikiBudaya memiliki Reviewer yang berasal dari ahli budaya dan komunitas budaya yang telah ditunjuk oleh Disbudpar Jatim (Muqtadiroh \& Pribadi, 2014). Adapun langkah pencarian artikel budaya dilakukan dengan tahapan pada Gambar 1 berikut ini.

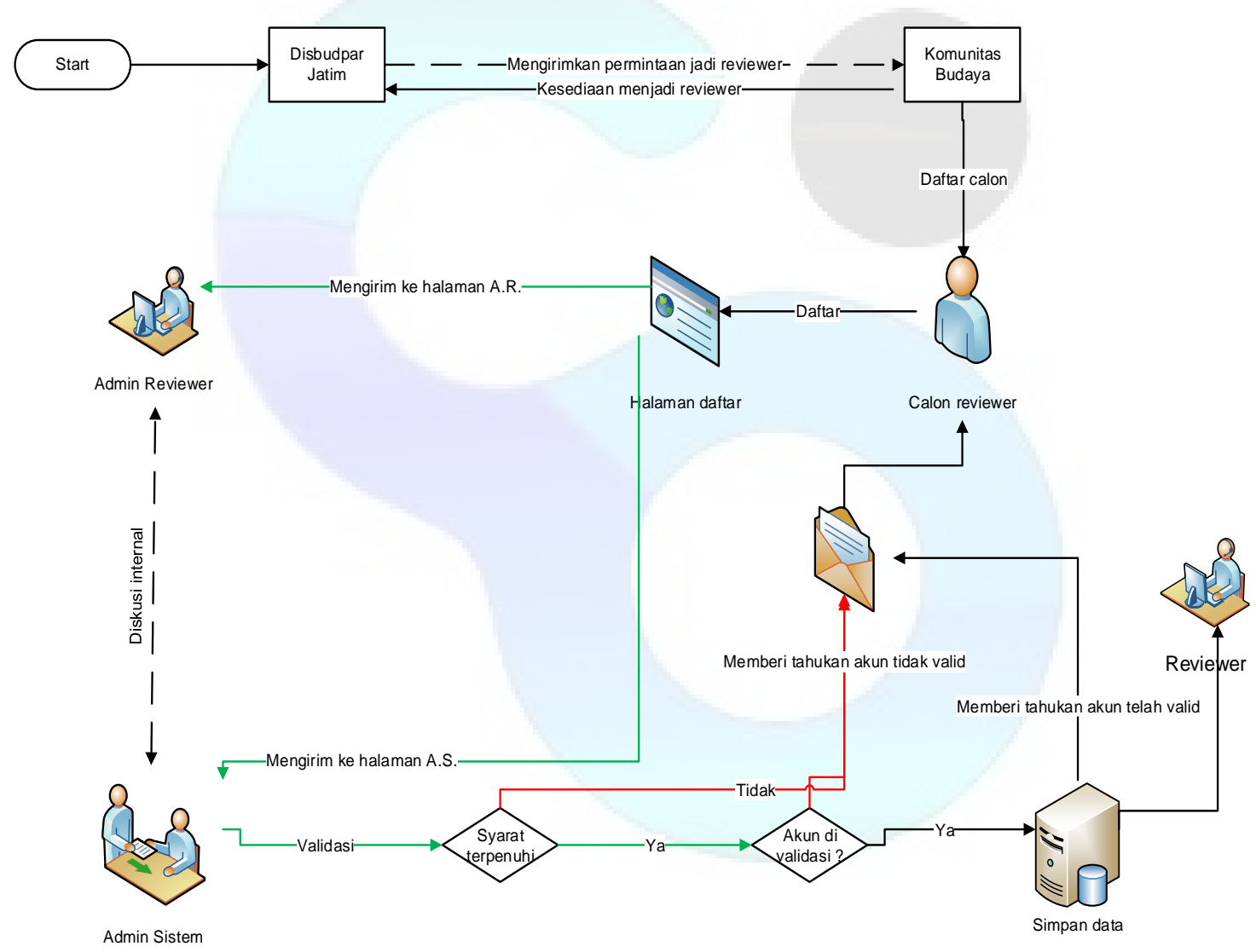

Gambar 1. Salah Satu Contoh Proses Bisnis pada Website WikiBudaya-Pencarian Artikel 


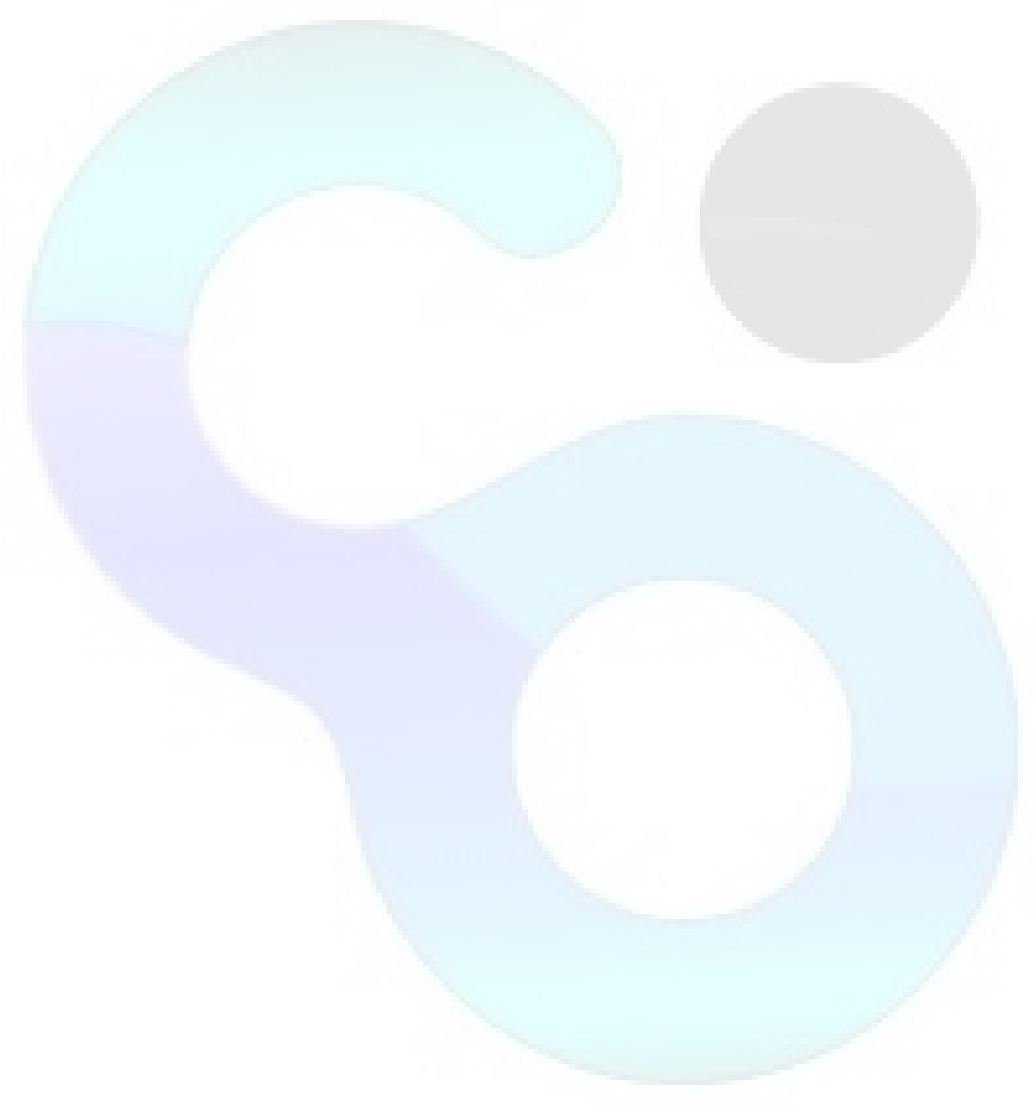


Muqtadiroh, dkk., Implementasi Perangkat Lunak WikiBudaya..

Pengguna yang berperan sebagai Kontributor memiliki hak akses untuk membuat dan mengirimkan artikel mengenai budaya Indonesia, serta memberikan masukan berupa komentar pada setiap artikel. Sedangkan peran sebagai Reviewer memiliki hak akses untuk melakukan review terhadap artikel-artikel budaya yang dibuat oleh pihak kontributor.

Terkait permasalahan implementasi perangkat lunak yakni bahwa Implementasi perangkat lunak terdiri dari aktivitas coding, testing, installation, documentation, training, support dan maintanance (Maryland, 2010). Coding yang merupakan proses membangun spesifikasi kebutuhan dan desain yang telah dibuat sebelumnya ke dalam kode - kode komputer oleh tim programmer. Testing yang merupakan proses ujicoba perangkat lunak untuk memastikan dari perangkat lunak. Installation merupakan proses pemasangan perangkat ke dalam lingkungan kerja pengguna. Documentation merupakan proses mengumpulkan seluruh informasi penting mengenai pengembangan perangkat lunak. Training merupakan proses mempersiapkan pengguna perangkat lunak secara teknis. Support dan maintanance merupakan proses pemeliharaan perangkat lunak serta pemberian dukungan teknis kepada pengguna perangkat lunak (Maryland, 2010).

Aktivitas - aktivitas diatas biasa dikerjakan secara terpisah oleh beberapa anggota tim proyek pengembangan perangkat lunak. Secara umum, pembagian aktivitas diatas akan dikelompokkan sesuai dengan tujuan dari tiap aktivitas. Pengerjaan aktivitas biasanya bergantung pada metode pengembangan perangkat lunak yang dipilih. Berikut pengelompokan aktivitas secara umum (Project Management Institute, 2001),

1. Aktivitas yang menjadikan sistem berfungsi secara operasional - coding, testing, dan instalasi

2. Aktivitas yang berkaitan dengan kegunaan dan penggunaan sistem secara operasional - dokumentasi, pelatihan dan dukungan penggunaan oleh pengguna

3. Aktivitas yang diperlukan untuk menjaga dan merawat kinerja sistem bekerja perawatan

Pada proyek pengembangan perangkat lunak WikiBudaya terdapat beberapa aktivitas yang telah dilakukan, aktivitas yang sedang berlangsung dan belum dilakukan karena menanti pengerjaan aktivitas yang lainnya terselesaikan. Aktivitas yang telah dilaksanakan adalah coding, dan testing. Sehingga pada penelitian kali ini akan dilakukan proses implementasi antara lain, instalasi, dokumentasi dan pelatihan pengguna.

\section{METODE PENELITIAN}

Tahap ini merupakan tahapan dimana metode penelitian ditentukan. Sebelumnya, tujuan dari penelitian sudah ditentukan yakni untuk melakukan implementasi terhadap perangkat lunak yang WikiBudaya sehingga dapat melestarikan kebudayaan dan kearifan lokal nusantara. Penelitian akan dilakukan dalam dua tahapan besar yakni perencanaan implementasi dan imlementasi yang digambarkan pada flowchart berikut,

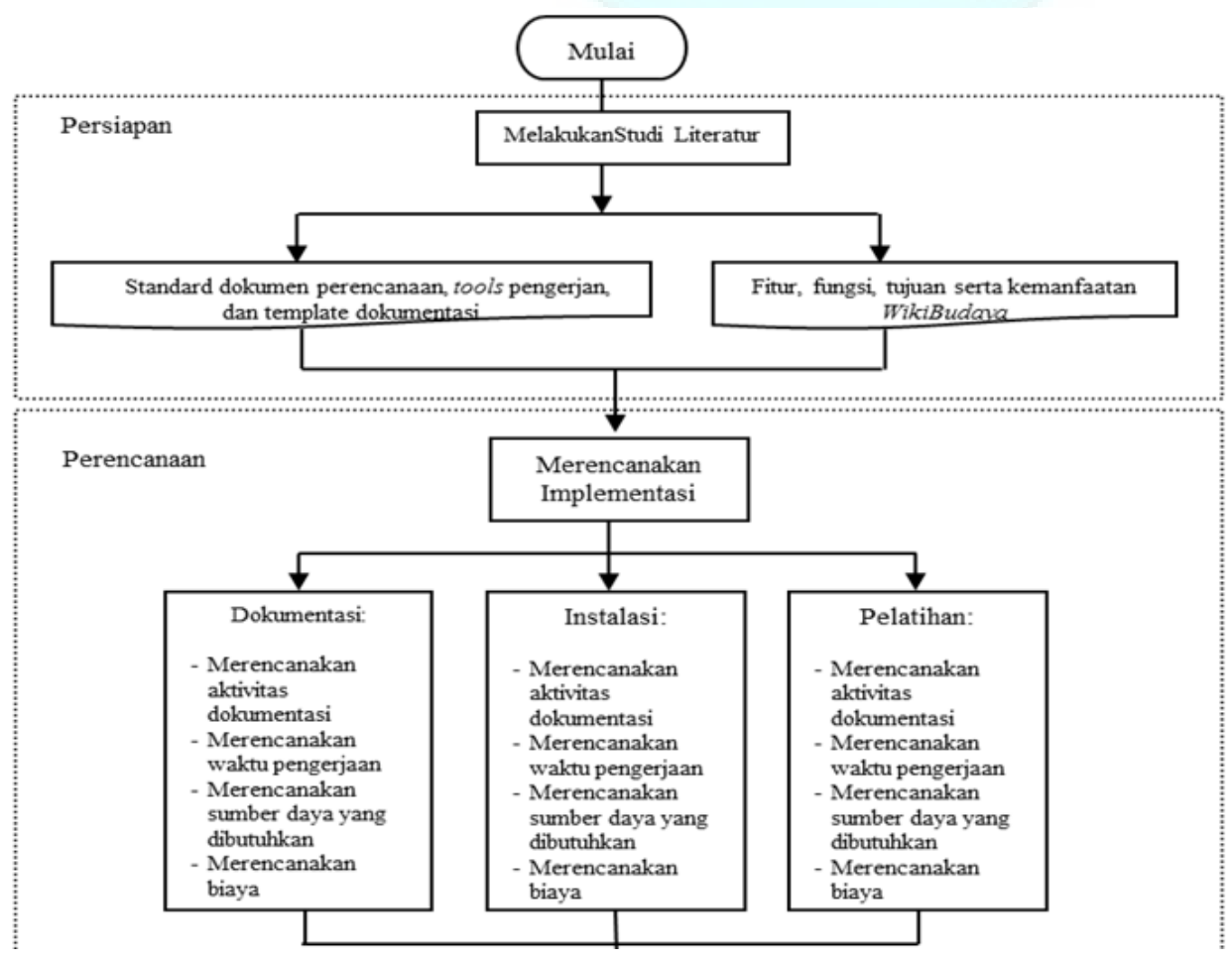




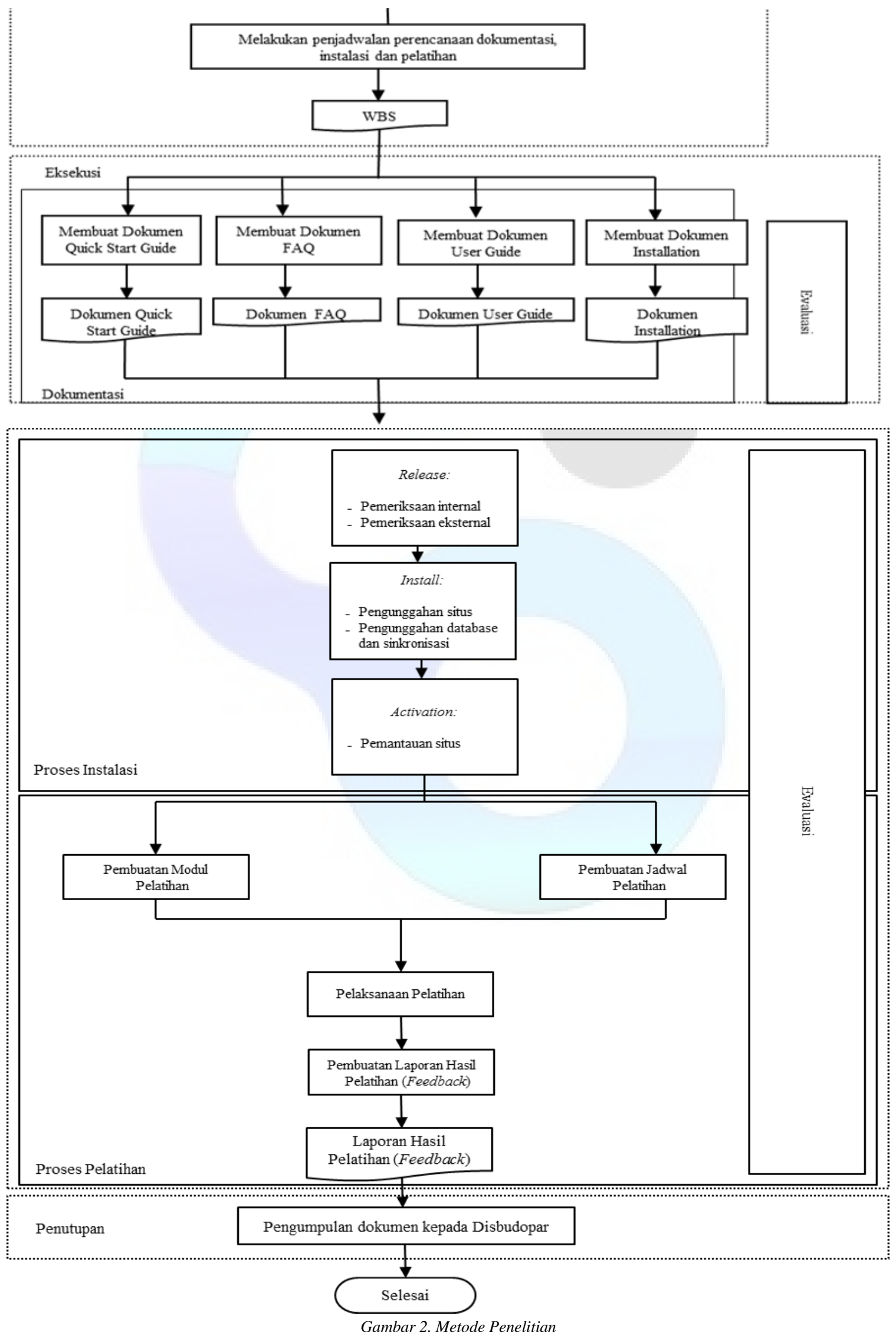




\subsection{Perencanaan Implementasi}

Perencanaan implementasi perangkat lunak adalah tahapan pengerjaan perancangan pengerjaan dan proses implementasi sebuah perangkat lunak. Secara umum perencanaan akan dibuat secara detail untuk tiap - tiap aktivitas implementasi yang akan dilaksanakan. Pada tiap tahap perencanaan aktivitas implementasi, akan dilakukan perencaanaan aktivitas, perencanaan penjadwalan, perencanaan sumber daya, dan perencanaan biaya. Pada perencanaan aktivitas, perencanaan yang dikerjakan adalah perencanaan urutan aktivitas (beserta sub-aktivitas) serta durasi pengerjaan aktivitas (beserta sub-aktivitas), kemudian setelah membuat perencanaan aktivitas baru dapat dilanjutkan pada perencanaan sumber daya yakni perencanaan sarana dan prasarana pendukung pelaksanaan tiap aktivitas. Selain sarana dan prasarana, tenaga kerja pada tiap aktivitas juga akan dijelaskan dan dipaparkan. Selanjutnya, perencanaan biaya yakni perencanaan estimasi dan penganggaran biaya pendukung dari pengerjaan aktivitas.

Perencanaan penjadwalan yakni proses membuat jadwal pengerjaan aktivitas (beserta sub-aktivitas) secara urut dan detail berdasarkan urutan pengerjaan aktivitas seserta siapa yang bertanggung jawab dan pengeluaran biaya dan penggunaan sumber daya. Sehingga perencanaan penjadwalan merupakan kompilasi perencanaan yang telah dilakukan sebelumnya. Perencanaan yang akan dibuat dalam sebuah struktur rincian pekerjaan atau work breakdown structure (WBS).

Perencanaan dalam bentuk WBS ini nantinya akan dijadikan pedoman dalam pelaksanaan aktivitas implementasi perangkat lunak Perencanaan yang dilakukan akan diklasifikasikan berdasarkan aktivitas implementasi yang akan dilakukan yakni perencanaan instalasi, perencanaan dokumentasi, dan perencanaan pelatihan pengguna akhir.

\subsection{Implementasi WikiBudaya}

Implementasi merupakan tahapan dimana pengerjaan aktivitas yang telah dirancang pada tahap perencanaan. Pelaksanaan aktivitas juga harus sesuai dengan waktu yang telah direncanakan. Pada tahapan ini setiap proses akan dipantau melalui dokumen work break down structure yang telah dibuat ditahap perencanaan. Implementasi diklasifikasikan ke dalam tiga proses besar yakni instalasi, perencanaan dokumentasi, dan perencanaan pelatihan pengguna akhir.

Pelaksanaan aktivitas juga harus sesuai dengan waktu yang telah direncanakan. Pada tahapan ini setiap proses akan dipantau melalui dokumen work break down structure yang telah dibuat ditahap planning menggunakan microsoft office project. Dalam tiap aktivitas juga akan langsung didakan evaluasi dan evaluasi akan dicatat karena kemudian evaluasi akan dikumpulkan dalam sebuah dokumen

\section{HASIL DAN PEMBAHASAN}

Hasil dari penelitian implementasi WikiBudaya terbagi menjadi 3 hal utama yakni Dokumentasi, Instalasi, dan Pelatihan Pengguna. Berikut adalah pembahasan dari masing-masing output penelitian.

\subsection{Dokumentasi}

Pengerjaan dokumentasi dimulai dengan persiaapan template untuk yakni template ready set. Penggunaan template readyset dibatasi hanya pada modul product content yang berisi template untuk dokumen quick start / installation guide, user guide dan Frequently Asked Question (FAQ). Dokumen quick start guide, user guide dan FAQ merupakan dokumen pengguna yang dihasilkan untuk membantu pengguna WikiBudaya untuk menggunakannya dan dokumen - dokumen ini akan digunakan juga sebagai modul saat pelatihan. Dokumen dokumen tersebut akan disatukan sebagai dokumen pengguna. Dokumen lainnya yang dihasilkan adalah dokumen instalasi (installation) yang hasilnya digunakan sebagai pedoman pemasangan WikiBudaya secara online pada aktivitas instalasi. Seluruh dokumen yang dihasilkan pada proses dokumentasi akan divalidasi sebelum dapat digunakan oleh penggunanya.

Metode validasi dilakukan dengan mencocokkan poin - poin yang terdapat pada template readyset dengan dokumen yang telah dibuat, apabila poin - poin tersebut ada dan dapat dibuktikan maka dokumen telah valid.

Tabel 1. Hasil Validasi Dokumen

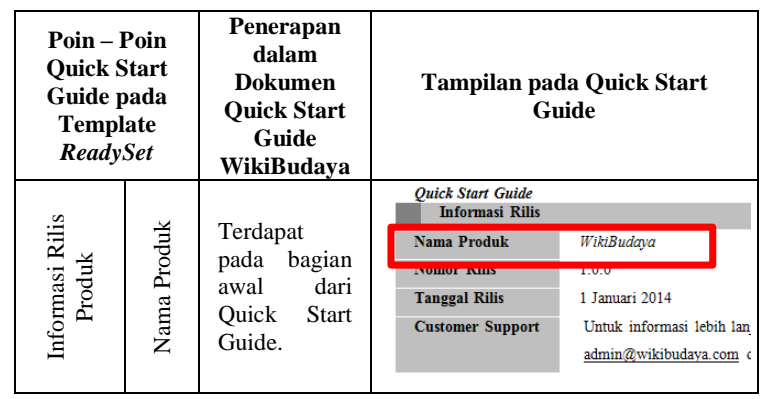




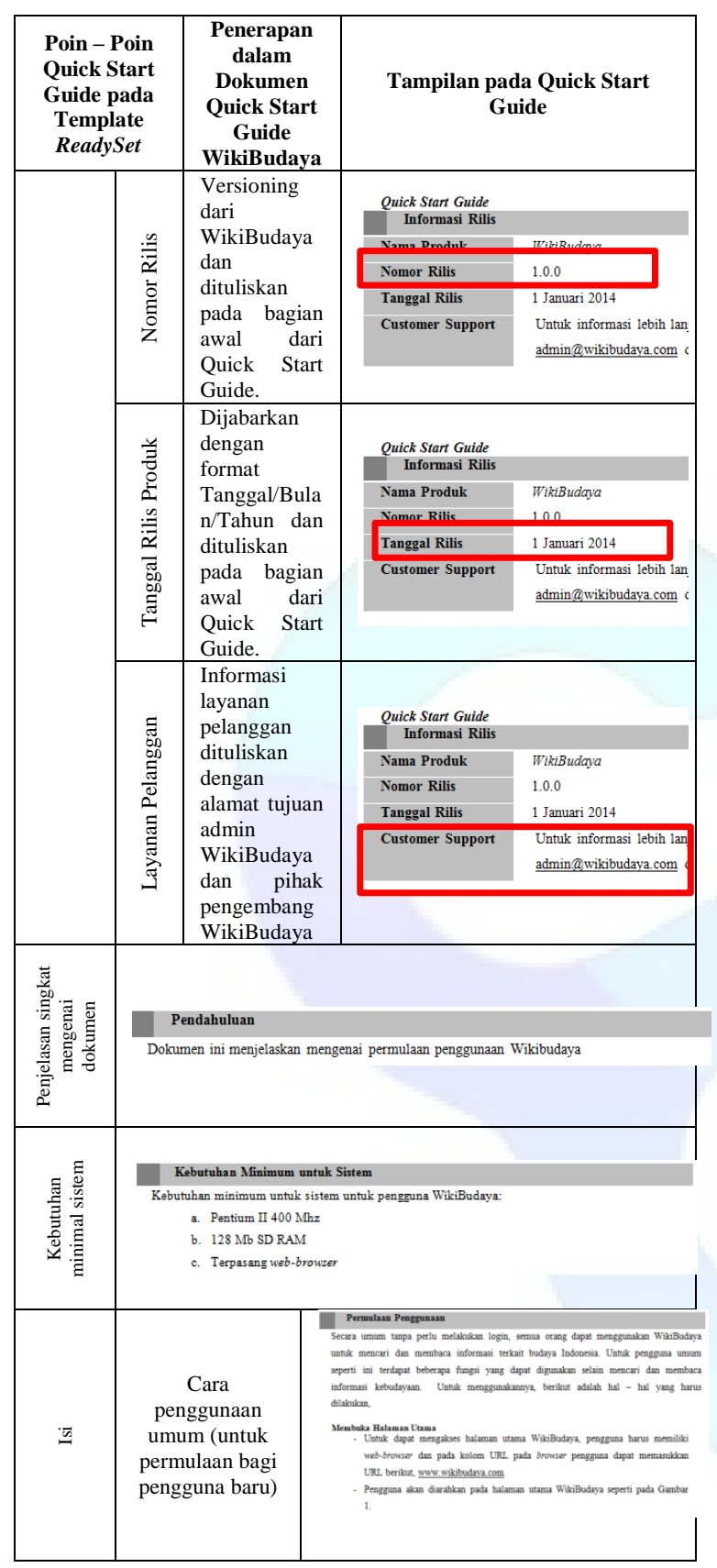

Dokumen quick start guide merupakan dokumen yang memaparkan mengenai penggunaan aplikasi untuk pengguna secara singkat. Pengerjaan dokumen quick start guide disesuaikan dengan kondisi situs WikiBudaya serta menggunakan template dari ReadySet (Labs, 2009).

Dokumen quick start guide terdapat pada bagian pertama pada dokumen pengguna.

Dokumen user guide merupakan dokumen yang memaparkan mengenai tata cara penggunaan WikiBudaya untuk para penggunanya secara detail. Pengerjaan dokumen user guide disesuaikan dengan kondisi situs WikiBudaya serta disusun sesuai dengan penggunaan dari tiap - tiap pengguna yang memiliki peran yang berbeda. Daftar peran pengguna yang ada pada WikiBudaya adalah Admin Setting, Admin Reviewer, Reviewer, dan Kontributor. Keempat pengguna tersebut memiliki peran dan akses yang berbeda, sehingga pembuatan user guide disesuaikan dengan kondisi tersebut.

Dokumen FAQ merupakan dokumen yang mengumpulkan perkiraan pertanyaan yang akan banyak dikeluarkan pengguna selama menggunakan situs WikiBudaya. Pengerjaan dokumen FAQ disesuaikan dengan kondisi situs WikiBudaya serta menggunakan template dari ReadySet.

Dokumen instalasi merupakan dokumen yang berisikan mengenai tata cara pemasangan WikiBudaya secara online sehingga dapat diakses oleh publik. Penulisan tata cara pemasangan dituliskan berdasarkan teknik dan prosedur pemasangan situs secara umum. Pada dokumen instalasi terdapat juga tata cara penghapusan WikiBudaya.

\subsection{Instalasi}

Instalasi merupakan proses dimana perangkat lunak WikiBudaya akan dipasang pada lingkungan pengguna. Pada proses instalasi akan dilakukan dengan metode instalasi direct. Prosesnya sendiri akan dilakukan secara runut dari tiga kegiatan utama yakni release, install dan activation.

Pada proses release terdapat dua kegiatan utama yakni pemeriksaan internal dan pemeriksaan eksternal. Keadaan internal dari sistem mempengaruhi performa sistem sehingga perlu diadakan pemeriksaan terkait dengan lingkungan internal sistem. Pemeriksaan kesiapan sistem juga sangat terkait dengan lingkungan eksternalnya sehingga selain memeriksa keadaan internal sistem dilakukan juga pemeriksaan pada keadaan eksternal sistem. Pada proses pemeriksaan internal dilakukan tiga kegiatan yakni, penambahan data, pemeriksaan fungsionalitas sistem, pemeriksaan model-viewcontroller dan perbaikan model-view-controller. Pada proses pemeriksaan eksternal dilakukan tiga kegiatan yakni, pemeriksaan perangkat keras, pemilihan dan pembelian domain dan hosting, pemeriksaan koneksi internet, dan aktivasi domain dan hosting.

Proses install merupakan proses dimana situs mulai disisipkan pada lingkungan pengguna. Proses yang terjadi didalamnya antara lain pengunggahan situs serta database. Selanjutnya, proses terakhir pada installation adalah activation. Activation merupakan proses dimana situs WikiBudaya mulai dipublikasikan dan dapat diakses secara luas oleh masyarakat. Selain proses publikasi, pada proses ini juga dilakukan 
proses pemantauan situs.

Pematauan situs WikiBudaya dilakukan dengan ujicoba terhadap beberapa faktor kualitas dengan mengujinya menggunakan tools yang telah ditentukan. Untuk itu faktor yang dipilih untuk diuji demi mengetahui ketahanan dan kehandalan situs adalah realibility, correctness, integrity dan portability. Keempat faktor kualitas dipilih karena tiap faktor dapat menjelaskan bagaimana performa dari situs WikiBudaya yang baru dipublikasikan ini. Metode yang digunakan sebagai metode ujicoba adalah blackbox testing karena pada pemantauan penguji bertindak sebagai pihak luar yang independen dan tidak terkait dengan pengembangan perangkat lunak dan memantau dari lingkup eksternal tanpa mengetahui mengenai keadaan internal dari perangkat lunak

\subsection{Pelatihan Pengguna}

Pelatihan pengguna merupakan aktivitas terakhir dari implementasi WikiBudaya. Pada aktivitas ini akan dilakukan sosialisasi penggunaan WikiBudaya terhadap tipe pengguna yang berperan aktif dalam pada WikiBudaya yakni Kontributor dan Reviewer. Pada aktivitas pelatihan akan dilakukan pembuatan jadwal pelatihan, pembuatan modul dan pelatihan pengguna. Pelatihan dilakukan secara parsial yakni dengan metode tutorial yang dilakukan dengan melakukan sosialisasi secara personal dan massal. Pelatihan tutorial dilakukan kepada peserta dengan golongan usia muda (15 tahun 35 tahun) yang dirasa memiliki wawasan mengenai komputer dan teknologi informasi cukup baik. Kemudian pelatihan tutorial banyak dilakukan untuk peserta dengan golongan usia tua (diatas 35 tahun) sehingga dapat memaksimalkan penambahan wawasan seputar teknologi informasi serta materi sosialisasi dengan baik.

Pada proses pelatihan peserta diberi lembar feedback sebagai salah satu sarana untuk menilai jalannya pelatihan dan yang paling utama adalah untuk melakukan penilaian terhadap WikiBudaya. Dari lembar feedback ini didapatkan beberapa masukan yang akan dirangkum sebagai saran pengembangan. Penilaian terhadap WikiBudaya didasarkan pada enam aspek yakni, penampilan situs, kemudahan penggunaan, efisiensi fitur, kesesuaian ekspektasi fitur, respon situs dan load time.

Aspek penampilan situs akan merepresentasikan mengenai bagaimana tampilan situs dimata pengguna. Aspek kemudahan penggunaan merupakan tingkat kesulitan penggunaan situs oleh ketika dilakukan eksplorasi situs secara mandiri. Aspek efisiensi merupakan bagaimana penilaian pengguna terhadap fitur - fitur yang ada baik secara tata letak maupun penggunaan, apakah fitur tersebut dirasa efisien atau tidak. Artinya bagaimana peran dari fitur - fitur yang ada apakah sudah bisa menyampaikan tujuannya atau belum. Ekspektasi pengguna pada fitur adalah bagaimana kesan pengguna ketika melihat situs dan beberapa fitur yang ada, pengguna biasanya mengharapkan beberapa fitur akan berjalan seperti yang mereka bayangkan. Setelah mencoba menggunakan fitur - fitur pada WikiBudaya apakah fitur - fitur tersebut dapat memenuhi apa yang diharapkan oleh pengguna atau belum. Respon situs merupakan aspek dimana pengguna menghitung kecepatan fitur untuk memenuhi permintaan serta hasil dari permintaan perubahan pengguna. Terakhir load time merupakan aspek penilaian terkait dengan waktu yang ditempuh oleh situs untuk menampilkan halaman.

Penilaian untuk mengambil poin - poin rekomendasi akan didasarkan pada total nilai rata - rata, total pemilih nilai minimum serta total pemilih nilai modus yang telah didapatkan pada hasil penghitungan sebelumnya. Berikut pada Tabel 2 dan Tabel 3 akan ditampilkan hasil penilaian serta rekomendasi yang muncul.

Tabel 2. Hasil Penilaian Situs oleh Peserta

\begin{tabular}{|c|c|c|}
\hline Aspek & Nilai Kontributor & Nilai Reviewer \\
\hline \multirow{3}{*}{$\begin{array}{l}\text { Penampilan } \\
\text { Situs }\end{array}$} & Rata - rata : 3 & Rata - rata : 2.4 \\
\hline & $\begin{array}{l}\text { Nilai minimal : } 2 \\
\text { (jumlah pemilih } 12 \text { ) }\end{array}$ & $\begin{array}{l}\text { Nilai minimal : } \\
1 \\
\text { (jumlah pemilih } \\
\text { 3) }\end{array}$ \\
\hline & $\begin{array}{l}\text { Nilai modus : } 3 \\
\text { (jumlah pemilih 26) }\end{array}$ & $\begin{array}{l}\text { Nilai modus: } 3 \\
\text { (jumlah pemilih } \\
11 \text { ) }\end{array}$ \\
\hline \multirow{3}{*}{$\begin{array}{l}\text { Kemudahan } \\
\text { Penggunaan }\end{array}$} & Rata - rata : 2.9 & Rata - rata : 2.9 \\
\hline & $\begin{array}{l}\text { Nilai minimal : } 1 \\
\text { (jumlah pemilih 1) }\end{array}$ & $\begin{array}{l}\text { Nilai minimal : } \\
1 \\
\text { (jumlah pemilih } \\
\text { 2) }\end{array}$ \\
\hline & $\begin{array}{l}\text { Nilai modus : } 3 \\
\text { (jumlah pemilih 26) }\end{array}$ & $\begin{array}{l}\text { Nilai modus: } 3 \\
\text { (jumlah pemilih } \\
8 \text { ) }\end{array}$ \\
\hline \multirow{3}{*}{$\begin{array}{l}\text { Efisiensi } \\
\text { Fitur }\end{array}$} & Rata-rata : 2.74 & Rata-rata : 3 \\
\hline & $\begin{array}{l}\text { Nilai minimal : } 1 \\
\text { (jumlah pemilih 1) }\end{array}$ & $\begin{array}{l}\text { Nilai minimal : } \\
2 \\
\text { (jumlah pemilih } \\
6 \text { ) }\end{array}$ \\
\hline & $\begin{array}{l}\text { Nilai modus : } 3 \\
\text { (jumlah pemilih 26) }\end{array}$ & $\begin{array}{l}\text { Nilai modus: } 3 \\
\text { (jumlah pemilih } \\
8 \text { ) }\end{array}$ \\
\hline \multirow{3}{*}{$\begin{array}{l}\text { Ekspektasi } \\
\text { Pengguna } \\
\text { pada Fitur }\end{array}$} & Rata-rata : 2.74 & Rata - rata : 2.4 \\
\hline & $\begin{array}{l}\text { Nilai minimal : } 1 \\
\text { (jumlah pemilih 1) }\end{array}$ & $\begin{array}{l}\text { Nilai minimal : } \\
1 \\
\text { (jumlah pemilih } \\
3 \text { ) }\end{array}$ \\
\hline & $\begin{array}{l}\text { Nilai modus : } 3 \\
\text { (jumlah pemilih } 34 \text { ) }\end{array}$ & $\begin{array}{l}\text { Nilai modus: } 3 \\
\text { (jumlah pemilih } \\
11 \text { ) }\end{array}$ \\
\hline \multirow[t]{2}{*}{ Respon Situs } & Rata - rata : 2.9 & Rata - rata : 2.4 \\
\hline & $\begin{array}{l}\text { Nilai minimal : } 1 \\
\text { (jumlah pemilih 12) }\end{array}$ & $\begin{array}{l}\text { Nilai minimal : } \\
1\end{array}$ \\
\hline
\end{tabular}




\begin{tabular}{|c|c|c|}
\hline Aspek & Nilai Kontributor & Nilai Reviewer \\
\hline & & $\begin{array}{l}\text { (jumlah pemilih } \\
\text { 3) }\end{array}$ \\
\hline & $\begin{array}{l}\text { Nilai modus : } 3 \\
\text { (jumlah pemilih 27) }\end{array}$ & $\begin{array}{l}\text { Nilai modus: } 3 \\
\text { (jumlah pemilih } \\
11 \text { ) }\end{array}$ \\
\hline \multirow[t]{3}{*}{ Load Time } & Rata - rata : 3.1 & Rata - rata : 2.4 \\
\hline & $\begin{array}{l}\text { Nilai minimal : } 1 \\
\text { (jumlah pemilih } 12 \text { ) }\end{array}$ & $\begin{array}{l}\text { Nilai minimal : } \\
1 \\
\text { (jumlah pemilih } \\
\text { 3) }\end{array}$ \\
\hline & $\begin{array}{l}\text { Nilai modus : } 3 \\
\text { (jumlah pemilih 28) }\end{array}$ & $\begin{array}{l}\text { Nilai modus: } 3 \\
\text { (jumlah pemilih } \\
11 \text { ) }\end{array}$ \\
\hline
\end{tabular}

Tabel 3. Rekomendasi untuk Pengembangan WikiBudaya

\begin{tabular}{|c|c|}
\hline Aspek & Rekomendasi \\
\hline \multirow{7}{*}{$\begin{array}{l}\text { Penampilan } \\
\text { Situs }\end{array}$} & $\begin{array}{l}\begin{array}{l}\text { Pemilihan tema } \\
\text { menarik }\end{array} \\
\end{array}$ \\
\hline & $\begin{array}{l}\text { Penggunaan box untuk penampilan } \\
\text { artikel }\end{array}$ \\
\hline & $\begin{array}{l}\text { Penampilan dan tata letak gambar } \\
\text { pada artikel }\end{array}$ \\
\hline & $\begin{array}{l}\text { Penampilan halaman untuk mengisi } \\
\text { artikel }\end{array}$ \\
\hline & $\begin{array}{lll}\begin{array}{l}\text { Penambahan } \\
\text { halaman utama }\end{array} & \text { informasi pada } \\
\end{array}$ \\
\hline & $\begin{array}{l}\text { Konsistensi penggunaan kata dalam } \\
\text { Bahasa Indonesia }\end{array}$ \\
\hline & $\begin{array}{l}\text { Optimasi tampilan pada mobile } \\
\text { device. }\end{array}$ \\
\hline \multirow{2}{*}{$\begin{array}{l}\text { Kemudahan } \\
\text { Penggunaan }\end{array}$} & $\begin{array}{l}\text { Mempertahankan kesederhanaan } \\
\text { fitur }\end{array}$ \\
\hline & $\begin{array}{l}\text { Penambahan prosedur } \\
\text { pembuatan artikel serta } \\
\text { artikel. }\end{array}$ \\
\hline \multirow{7}{*}{ Efisiensi Fitur } & $\begin{array}{l}\text { Pemberian informasi pada halaman } \\
\text { utama (About) }\end{array}$ \\
\hline & $\begin{array}{l}\text { Pemberian informasi terkait } \\
\text { penggunaan situs kepada pengguna } \\
(\text { FAQ dan Help) }\end{array}$ \\
\hline & $\begin{array}{l}\text { Penghapusan fungsi mandatory } \\
\text { pada pengunggahan gambar saat } \\
\text { menambah artikel }\end{array}$ \\
\hline & $\begin{array}{l}\text { Perbaikan pada tampilan } \\
\text { penambahan artikel, tidak perlu ada } \\
\text { pemisahan antara sejarah, isi, dan } \\
\text { pendahuluan. }\end{array}$ \\
\hline & $\begin{array}{l}\text { Penambahan kategori dan membuat } \\
\text { kategori lebih bebas sehingga } \\
\text { fungsinya seperti tag }\end{array}$ \\
\hline & Penambahan fitur featured article \\
\hline & $\begin{array}{l}\text { Penambahan rating dan } \\
\text { penghargaan untuk Kontributor dan } \\
\text { Reviewer }\end{array}$ \\
\hline \multirow{4}{*}{$\begin{array}{l}\text { Ekspektasi } \\
\text { Pengguna } \\
\text { terhadap Fitur }\end{array}$} & $\begin{array}{l}\text { Perbaikan pada fitur - fitur yang } \\
\text { masih mengalami kegagalan }\end{array}$ \\
\hline & $\begin{array}{l}\text { Perbaikan pada tampilan situs sesuai } \\
\text { dengan rekomendasi yang telah } \\
\text { dibahas pada aspek penampilan situs }\end{array}$ \\
\hline & $\begin{array}{l}\text { Penambahan beberapa fitur yang } \\
\text { dirasa perlu seperti Help, FAQ serta } \\
\text { About }\end{array}$ \\
\hline & $\begin{array}{lll}\begin{array}{l}\text { Penambahan } \\
\text { validasi artikel }\end{array} & \text { prosedur } & \text { terkait } \\
\end{array}$ \\
\hline
\end{tabular}

\begin{tabular}{|c|c|c|}
\hline Aspek & & Rekomendasi \\
\hline \multirow{2}{*}{\multicolumn{2}{|c|}{$\begin{array}{ll}\text { Respon } & \text { Situs } \\
\text { dan } & \text { Load } \\
\text { Time } & \end{array}$}} & Penambahan kuota hosting \\
\hline & & $\begin{array}{l}\text { Mempertahankan kesederhanaan } \\
\text { fitur untuk menjaga waktu } \\
\text { penayangan halaman. }\end{array}$ \\
\hline
\end{tabular}

\section{KESIMPULAN DAN SARAN}

\subsection{Kesimpulan}

1. Metode WBS dan Gantt Chart yang diterapkan membantu menghindari kegagalan penyelesaian proyek karena pada saat terdesak permasalahan administrasi dapat segera membuat keputusan untuk melangkah ke aktivitas selanjutnya. Pengerjaan aktivitas yang telah direncanakan pada baseline WBS mencapai $85 \%$ dari total aktivitas yang telah dibuat. Aktivitas yang tidak terlaksana sebagian besar terdapat pada proses pelatihan. Kegagalan yang terjadi pada proses pelatihan, mengakibatkan perubahan pada metode yang digunakan untuk melakukan pelatihan pengguna. Selain itu, terdapat aktivitas tambahan yang tidak dicantumkan pada baseline WBS. Aktivitas tersebut adalah aktivitas ujicoba perangkat lunak untuk pemantauan situs.

2. Dokumen pengguna yang dihasilkan pada proses dokumentasi digunakan sebagai modul untuk pelatihan pengguna dan sebaiknya ditambahkan pada situs WikiBudaya untuk pedoman penggunaan situs.

3. Dokumen instalasi yang dihasilkan digunakan sebagai pedoman instalasi situs WikiBudaya pada proses instalasi.

4. Pelatihan yang dilakukan kepada Kontributor dan Reviewer menghasilkan lembar feedback peserta yang digunakan sebagai data untuk menyajikan rekomendasi pengembangan situs WikiBudaya selanjutnya. Rekomendasi yang diberikan kepada pengembang terkait dengan aspek - aspek kebutuhan umum serta interaksi situs dengan pengguna yakni, penampilan situs, kemudahan penggunaan, efisiensi fitur, ekpektasi pengguna terhdap fitur situs dan waktu yang dibutuhkan situs untuk menampilkan halaman.

\subsection{Saran}

1. Manajer proyek diharapkan menjalin komunikasi aktif dengan pihak stakeholder sehingga tidak terjadi permasalahan yang dapat menghambat proyek implementasi WikiBudaya. Termasuk komunikasi dalam tim diharapkan aktif dan lebih efektif sehingga kegagalan fitur yang ada pada 
Muqtadiroh, dkk., Implementasi Perangkat Lunak WikiBudaya..

aplikasi dapat dibenahi dengan segera dan tidak menghambat proses implementasi. Untuk itulah pentingnya dilakukan penelitian lebih lanjut terkait manajemen komunikasi untuk mencapai keberhasilan implementasi perangkat lunak. Komunikasi yang efektif menjadi salah satu faktor penting yang menentukan berhasil atau tidaknya proyek implementasi suatu perangkat lunak. Melalui suatu dokumen perencanaan manajemen komunikasi diharapkan mampu menjadi suatu alat kontrol untuk memastikan kegiatan komunikasi dapat berjalan secara efektif dan efisien selama proyek dieksekusi.

2. Terkait dokumentasi yang merupakan salah satu produk dalam proses implementasi perangkat lunak, sebaiknya kedepan dengan menggunakan standar dokumen berbasis ISO untuk menghasilkan suatu dokumen yang komprehensif dan valid. Dapat digunakan beberapa standar seperti IEEE STD 26514-2010, IEEE STD 10632001, ISO IEC 26514-2008, dan atau ISO/IEC 26513:2009. Hal ini bertujuan agar proses implementasi perangkat lunak dapat berjalan optimal.

\section{DAFTAR PUSTAKA}

Ahmad, M., Feby Artwodini, M., Amna Shifia, N., \& Ika, N. (2012).

VirtualNUSANTARA: A KNOWLEDGE MANAGEMENT SYSTEM FRAMEWORK FOR CULTURAL HERITAGE AND LOCAL WISDOM CONSERVATION in INDONESIA. In International Conference on Sustainable Development (ICSD).

Feby Artwodini, M., Amna Shifia, N., \& Mochammad, M. (2014). PEMBANGUNAN PERANGKAT LUNAK WIKIBUDAYA DALAM RANGKA MELESTARIKAN BUDAYA BANGSA DAN KEARIFAN LOKAL INDONESIA. In Seminar Sistem Informasi Indonesia - SESINDO ITS.

Jeffrey A. Hoffer, Joey F. George, J. S. V. (2012). Essentials of System Analysis \& Design. (I. Pearson Education, Ed.) (Fifth Edit.). New Jersey: Prentice Hall.

Labs, M. (2009). ReadySET Pro Document Map. Retrieved from http://www.readysetpro.com/eval/eval.ht $\mathrm{ml}$

Maryland, G. of. (2010). System Development Life Cycle (pp. 1-12). Department of Information Technology.

Muqtadiroh, F. A., \& Pribadi, A. (2014). PENELITIAN PEMULA ITS:

PENGEMBANGAN DAN IMPLEMENTASI WIKIBUDAYA WEBSITE INFORMATIF KONSERVASI BUDAYA DAN KEARIFAN LOKAL INDONESIA (virtualNUSANTARA). Surabaya.

Project Management Institute, I. (2001). A Guide to Project Management Body of Knowledge (PMBOK Guide) (5th editio., pp. 47-307). Pennsylvania: PMI Publishing Division.

Samantha, G. (2011). Apa Saja Faktor Punahnya Bahasa Etnis di Indonesia. Retrieved from http://nationalgeographic.co.id/berita/201 1/12/apa-saja-faktor-punahnya-bahasaetnis-di-indonesia

Sasongko, A. (2011). Alasan Kekayaan Budaya Indonesia Mudah Diklaim.

StandishGroup. (2010). Penyebab Kegagalan IT Project. Artikel IT Klinik, 113.

Suryanto, Gondodiyoto, S., NI, D., Aryanto, \& Triana, E. (2009). Evaluasi Manajemen Proyek. CommIT, 3(2), 82-85. 


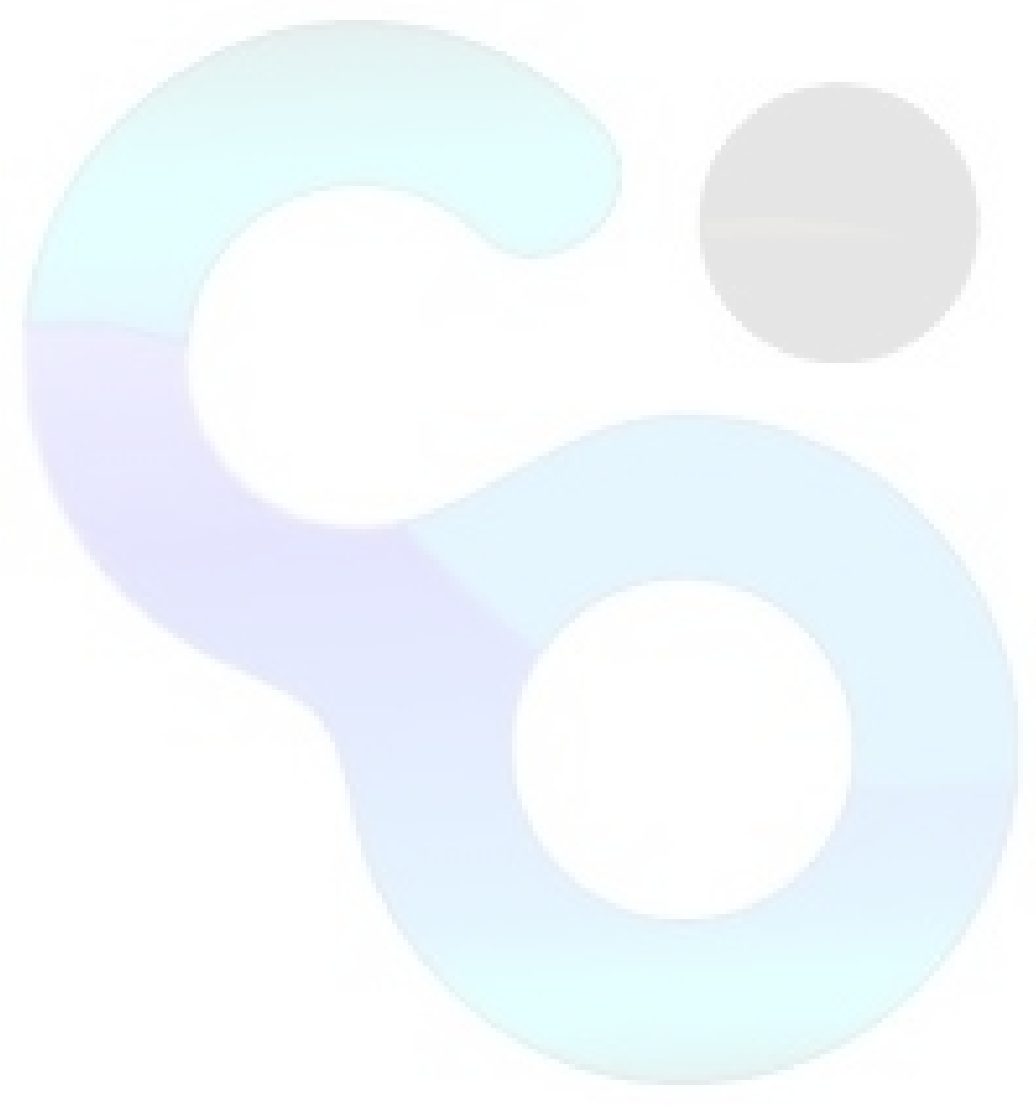

